JANUSZ J. WĘC

Kraków

\title{
Reforma systemu instytucjonalnego Unii Europejskiej przewidywana w Traktacie lizbońskim
}

\section{Uwagi wstępne}

W niniejszym artykule zaprezentowana zostanie reforma systemu instytucjonalnego Unii Europejskiej, przewidywana w Traktacie lizbońskim, który został podpisany 13 grudnia 2007 r. w stolicy Portugalii przez szefów państw lub rządów dwudziestu siedmiu krajów członkowskich Unii. Przedmiotem analizy są: zasady określające system instytucjonalny Unii Europejskiej oraz zmiany w funkcjonowaniu instytucji i organów Unii. Jednocześnie zrezygnowano w niniejszym artykule ze szczegółowego omówienia zmian dotyczących funkcjonowania urzędu przewodniczącego Rady Europejskiej, urzędu wysokiego przedstawiciela Unii do spraw zagranicznych i polityki bezpieczeństwa, a także nowych zasad działania prezydencji w Unii Europejskiej. Zostały one bowiem przedstawione w innym miejscu ${ }^{1}$. Należy podkreślić, że reforma systemu instytucjonalnego Unii Europejskiej stanowi jedynie jeden z ośmiu głównych aspektów reformy ustrojowej Unii, skodyfikowanej w Traktacie lizbońskim, obok takich znaczących zmian systemowych, jak: przekształcenie Unii w jednolitą organizację międzynarodową w rozumieniu prawa międzynarodowego, rozszerzenie wspólnej aksjologii Unii; podział kompetencji między Unią a państwami członkowskimi, usystematyzowanie katalogu aktów prawnych i uproszczenie procedur prawodawczych; wzmocnienie roli parlamentów narodowych państw członkowskich w procesie legislacyjnym Unii, modyfikacje w procedurze rewizji traktatów, a także zmiany w funkcjonowaniu wzmocnionej współpracy. Z drugiej strony, należy podkreślić, że reforma ustrojowa Unii Europejskiej charakteryzuje się pewnymi ułomnościami. Utrzymana bowiem zostaje Europejska Wspólnota Energii Atomowej jako odrębna organizacja międzynarodowa. Zachowane zostają także podstawowe osobliwości i specyfika wspólnej polityki zagranicznej i bezpieczeństwa oraz współpracy policyjnej i sądowej w sprawach karnych ${ }^{2}$.

1 Szerzej na ten temat por. J. J. Węc, Nowy model prezydencji w Unii Europejskiej po zmianach zaproponowanych $w$ traktacie lizbońskim, ,Rocznik Integracji Europejskiej” 2008, nr 2, s. 43-54.

2 Szerzej na ten temat por. J. Barcz (red.), Prawo Unii Europejskiej, Zagadnienia systemowe, Warszawa 2006; idem, Poznaj Traktat z Lizbony, Warszawa 2008; idem, Przewodnik po Traktacie $z$ Lizbony. Traktaty stanowiqce Unię Europejskq. Stan obecny oraz teksty skonsolidowane w brzmieniu Traktatu z Lizbony, Warszawa 2008. 


\section{Systematyka przepisów traktatowych dotyczących systemu instytucjonalnego Unii Europejskiej}

Przepisy ogólne dotyczące ram instytucjonalnych oraz kompetencji instytucji i organów Unii Europejskiej, z wyjątkiem Trybunału Obrachunkowego i Europejskiego Banku Centralnego (EBC), umieszczone zostały w Tytule III („Postanowienia o instytucjach”) Traktatu o Unii Europejskiej (TUE). Natomiast postanowienia szczegółowe, odnoszące się do uprawnień oraz zasad funkcjonowania wszystkich instytucji i organów Unii Europejskiej oraz Unii Gospodarczej i Walutowej znalazły się w Części szóstej, Tytule I („Postanowienia instytucjonalne i finansowe”) Traktatu o funkcjonowaniu Unii Europejskiej (TFUE) ${ }^{3}$.

\section{Zasady określające system instytucjonalny Unii Europejskiej}

Na mocy Traktatu lizbońskiego do TUE i TFUE wprowadzone zostają istotne, choć niezbyt radykalne zmiany w systemie instytucjonalnym przyszłej Unii Europejskiej. Nie ma on zatem przełomowego znaczenia w dotychczasowym rozwoju tego systemu. Traktat ustanawia po raz pierwszy system instytucjonalny Unii Europejskiej, co jest m.in. następstwem przekształcenia Unii w organizację międzynarodową oraz uniwersalnej sukcesji przyszłej Unii wobec Wspólnoty Europejskiej i obecnej Unii. Dookreśla on również zasadę jednolitych ram instytucjonalnych, stanowiąc, że winny one służyć: wspieraniu wartości Unii, realizacji jej celów, jej interesom, interesom jej obywateli i państw członkowskich, a także zapewnieniu spójności, skuteczności i ciągłości jej polityk oraz działań. Traktat rozszerza również ramy instytucjonalne Unii Europejskiej, ustanawiając Radę Europejską i Europejski Bank Centralny nowymi instytucjami Unii (art. 13 ust. 1 TUE). Nadaje on także status traktatowy zasadzie lojalnej współpracy międzyinstytucjonalnej, choć nie określa, na czym dokładnie miałaby ona polegać. Postanawia jedynie, że instytucje mają ze sobą lojalnie współpracować (art. 13 ust. 2 TUE) ${ }^{4}$. Traktat przewiduje również, że Parlament Europejski, Rada i Komisja Europejska powinny konsultować się wzajemnie, a także, za wspólnym porozumieniem, ustalać warunki współpracy. W tym celu mogą one, w poszanowaniu traktatów, zawierać porozumienia międzyinstytucjonalne, mające wiążący charakter (art. 295 TFUE) ${ }^{5}$.

3 Traktat z Lizbony, zmieniajacy traktat o Unii Europejskiej i traktat ustanawiajacy Wspólnotę Europejska (dalej - Traktat z Lizbony), Lizbona, 13 grudnia 2007 r., (tekst skonsolidowany), Dziennik Urzędowy Unii Europejskiej C, 2008, nr 115, s. 2-16.

4 Traktat z Lizbony, op. cit., s. 28.

Traktat z Lizbony, op. cit., s. 229. Już deklaracja nr 3 w sprawie art. 10 Traktatu ustanawiającego Wspólnotę Europejska, zawarta w Akcie Końcowym konferencji międzyrządowej 2000 r., załączonym do Traktatu nicejskiego, wyraźnie wskazywała, że „obowiązek lojalnej współpracy”, który wynika z postanowień tegoż artykułu, reguluje nie tylko stosunki między państwami członkowskimi a instytucjami wspólnotowymi, ale także „stosunki między instytucjami Wspólnoty”. Jeśli okaże się to niezbędne, to spełniając obowiązek lojalnej współpracy, Parlament Europejski, Rada Unii Europejskiej i Komisja Europejska mogą zawierać porozumienia międzyinstytucjonalne w celu ułatwiania stosowania postanowień Traktatu ustanawiającego Wspólnotę Europejską. Porozumienia takie nie moga jednak zmieniać ani uzupełniać postanowień Traktatu i mogą być zawierane jedynie za 
Traktat potwierdza również zasadę autonomii kompetencyjnej, stanowiąc, że każda z instytucji Unii „działa w granicach uprawnień przyznanych jej na mocy Traktatów, zgodnie z procedurami, na warunkach oraz w celach w nich określonych" (art. 13 ust. 2 TUE). Nie nadaje on wprawdzie statusu traktatowego zasadzie równowagi instytucjonalnej, ale potwierdza, stanowiące ogólne źródło tej zasady, postanowienia art. 4 ust. 1 TWE (obecnie art. 7 ust. 1 TWE), odwołując się do zasady autonomii kompetencyjnej (art. 13 ust. 2 TUE) ${ }^{6}$.

\section{Rada Europejska}

Traktat lizboński, wprowadzając zmiany do TUE i TFUE, umacnia pozycję Rady Europejskiej w systemie instytucjonalnym Unii Europejskiej. Rada Europejska uzyskuje po raz pierwszy status instytucji. Traktat ustanawia nowy urząd stałego przewodniczącego Rady Europejskiej oraz zmienia jej dotychczasowy skład. Rozszerzeniu ulegają również uprawnienia decyzyjne (ale nie prawodawcze), wyborcze i nominacyjne Rady Europejskiej, co w istotny sposób wzmacnia całą infrastrukturę międzyrządową w Unii Europejskiej.

Przewodniczący Rady Europejskiej jest wybierany i odwoływany przez Radę Europejską większością kwalifikowaną na okres dwóch i pół roku. Mandat przewodniczącego jest jednokrotnie odnawialny (art. 15 ust. 5 TUE). Przewodniczący Rady Europejskiej nie może pełnić mandatu narodowego, czyli sprawować krajowej funkcji publicznej (art. 15 ust. 6 TUE). Do uprawnień przewodniczącego Rady Europejskiej należy: przewodniczenie Radzie Europejskiej i prowadzenie jej prac (art. 15 ust. 6 TUE); zapewnianie przygotowania i ciagłości prac Rady Europejskiej we współpracy z przewodniczącym Komisji Europejskiej i na podstawie prac Rady do Spraw Ogólnych (art. 15 ust. 6 TUE); wspomaganie osiagania spójności i konsensu w Radzie Europejskiej (art. 15 ust. 6 TUE); przedstawianie Parlamentowi Europejskiemu sprawozdania z każdego posiedzenia Rady Europejskiej (art. 15 ust. 6 TUE); zapewnianie na swoim poziomie oraz $\mathrm{w}$ zakresie swojej właściwości reprezentacji Unii Europejskiej na zewnątrz w sprawach dotyczących wspólnej polityki zagranicznej i bezpieczeństwa, bez uszczerbku dla uprawnień wysokiego przedstawiciela Unii do spraw zagranicznych i polityki bezpieczeństwa (art. 15 ust. 6 TUE); zwoływanie posiedzeń Konwentu (art. 48 ust. 3 TUE) ${ }^{7}$. Na pierwszy rzut oka uprawnienia przewodniczącego Rady Europejskiej odpowiadają dotychczasowym jego kompetencjom. W rzeczywistości jednak są one szersze, jeżeli zestawić je z - omówionymi niżej - nowymi kompetencjami decyzyjnymi i nominacyjnymi Rady Europejskiej uzyskanymi w Traktacie lizbońskim.

zgodą tych trzech instytucji; por. Deklaracja w sprawie art. 10 Traktatu ustanawiajacego Wspólnote Europejska, w: Traktat z Nicei, zmieniajacy traktat o Unii Europejskiej, traktaty ustanawiajace Wspólnoty Europejskie i niektóre zwiqzane z nimi akty, http//www.msz.gov.pl/, s. 55.

6 Traktat z Lizbony, op. cit., s. 28; por. też K. A. Wojtaszczyk, Instytucje w systemie politycznym Unii Europejskiej, w: K. A. Wojtaszczyk (red.), System instytucjonalny Unii Europejskiej, Warszawa 2005, s. 18.

7 Traktat z Lizbony, op. cit., s. 30, 56. 
Traktat zmienia skład Rady Europejskiej. Członkami Rady Europejskiej są szefowie państw lub rządów, przewodniczący Rady Europejskiej i przewodniczący Komisji Europejskiej. W jej pracach ma również uczestniczyć wysoki przedstawiciel Unii do spraw zagranicznych i polityki bezpieczeństwa (art. 15 ust. 2 TUE). W odróżnieniu od obowiązujących dotąd regulacji, ministrowie rządów państw członkowskich, a zatem zarówno ministrowie spraw zagranicznych, jak i szefowie innych resortów, mogą być zapraszani na posiedzenia Rady Europejskiej na mocy decyzji szefów państw lub rządów, choć jedynie wtedy, gdy wymaga tego porządek obrad. To samo dotyczy członka Komisji Europejskiej, towarzyszącego przewodniczącemu Komisji. Rada Europejska zbiera się dwa razy w ciagu półrocza i jest zwoływana przez jej przewodniczącego (art. 15 ust. 3 TUE) ${ }^{8}$.

Podobnie jak dotychczas Rada Europejska nadaje impulsy niezbędne do rozwoju oraz określa ogólne kierunki i priorytety polityczne Unii. Traktat wyraźnie stwierdza również, że Rada Europejska nie może pełnić funkcji prawodawczych (art. 15 ust. 1 TUE). Jeżeli traktaty nie stanowią inaczej, Rada Europejska ma podejmować swoje decyzje w drodze konsensu (art. 15 ust. 4 TUE). Może ona jednak także stanowić większością kwalifikowaną, ale wówczas jej przewodniczący i przewodniczący Komisji Europejskiej nie biorą udziału w głosowaniu (art. 235 ust. 1 TFUE).

Uprawnienia decyzyjne Rady Europejskiej mają charakter instytucjonalny i polityczny. Do uprawnień decyzyjnych o charakterze instytucjonalnym, nadanych Radzie Europejskiej na mocy Traktatu lizbońskiego, należą m.in.: decyzja określająca nowy skład Parlamentu Europejskiego (art. 14 ust. 2 TUE); decyzja określająca liczbę nowych formacji Rady (art. 236 TFUE); decyzja w sprawie zasad rotacyjnej prezydencji w Radzie, z wyjątkiem Rady do Spraw Zagranicznych (art. 236 TFUE, deklaracja nr 9), a także decyzja w sprawie zasad równościowej rotacji w składzie Komisji Europejskiej (art. 244 TFUE) ${ }^{9}$.

Uprawnienia decyzyjne Rady Europejskiej o charakterze politycznym wyrażają się m.in. w określaniu strategicznych interesów Unii (art. 15 ust. 1 TUE); ustalaniu celów wspólnej polityki zagranicznej i bezpieczeństwa Unii (art. 26 ust. 1 TUE); podejmowaniu decyzji o stworzeniu wspólnej obrony (art. 42 ust. 2 TUE); ustalaniu strategicznych wytycznych na temat prawodawczej i operacyjnej działalności w przestrzeni wolności bezpieczeństwa i sprawiedliwości (art. 68 TFUE); podejmowaniu decyzji o zmianie trybu podejmowania decyzji z jednomyślnego na tryb większości kwalifikowanej w dziedzinie wspólnej polityki zagranicznej i bezpieczeństwa (art. 31 ust. 3 TUE), ustalaniu wytycznych w sprawie negocjacji na temat traktatu o dobrowolnym wystapieniu z Unii (art. 50 ust. 2 TUE), podejmowaniu decyzji w sprawie mandatu dla konferencji międzyrządowych (art. 48 ust. 3 TUE), weryfikacji propozycji rewizji traktatów zgodnie ze zwykłą procedurą ich rewizji (art. 48 ust. 3 TUE), a także podejmowaniu decyzji w sprawie wszczęcia dwóch procedur uproszczonej rewizji traktatów

8 Ibidem, s. 29-30, 200.

9 Ibidem, s. 29, 200, 203-204; Deklaracja odnoszaca się do artykutu 16 ustęp 9 Traktatu o Unii Europejskiej dotyczaca decyzji Rady Europejskiej w sprawie sprawowania prezydencji Rady, s. $431-433$. 
(art. 48 ust. 6-7 TUE). Pięć ostatnich spośród tych postanowień nadane zostało Radzie Europejskiej na mocy Traktatu lizbońskiego ${ }^{10}$.

Pierwsza z dwóch wspomnianych procedur uproszczonej rewizji traktatów dotyczy wszystkich lub niektórych postanowień Części trzeciej TFUE, obejmującej wewnętrzne polityki i działania Unii. W jej ramach Rada Europejska, stanowiąc jednomyślnie, po konsultacji z Parlamentem Europejskim i Komisją Europejską oraz Europejskim Bankiem Centralnym w sprawach dotyczących zmian instytucjonalnych w dziedzinie polityki monetarnej, może podjąć decyzję zmieniającą wszystkie lub niektóre postanowienia Traktatu dotyczące polityk i działań wewnętrznych Unii Europejskiej. Jednak decyzja Rady Europejskiej wchodzi w życie dopiero po jej ratyfikacji przez wszystkie państwa członkowskie Unii zgodnie z ich odpowiednimi wymogami konstytucyjnymi (art. 48 ust. 6 TUE). Druga procedura uproszczonej rewizji traktatów odnosi się do podejmowania decyzji oraz procedury prawodawczej w TFUE lub Tytule V TUE, obejmującym postanowienia ogólne o działaniach zewnętrznych Unii i postanowienia szczególnie dotyczące wspólnej polityki zagranicznej i bezpieczeństwa Unii. Procedura ta stanowi, że Rada Europejska może przyjąć decyzję upoważniającą Radę do stanowienia większością kwalifikowaną w dziedzinach, w których TFUE lub Tytuł V TUE przewidują głosowanie jednomyślne w Radzie (z wyjątkiem decyzji mających wpływ na kwestie wojskowe i obronne) lub że Rada Europejska może podjąć decyzję zezwalającą na przyjęcie aktów prawodawczych zgodnie ze zwykłą procedurą prawodawczą w przypadkach, w których TFUE przewiduje przyjmowanie aktów prawodawczych przez Radę zgodnie ze specjalną procedurą prawodawczą. Wszystkie inicjatywy podejmowane przez Radę Europejską w tych dwóch sprawach są przekazywane parlamentom narodowym. Jeśli jednak nawet tylko jeden z nich wyrazi swój sprzeciw w ciagu sześciu miesięcy od daty takiego przekazania, procedura ta nie może być doprowadzona do końca (art. 48 ust. 7 TUE) ${ }^{11}$.

Uprawnienia nominacyjne Rady Europejskiej, nadane jej na mocy Traktatu lizbońskiego, polegają na wyborze i odwoływaniu przewodniczącego Rady Europejskiej (art. 15 ust. 5 TUE); wyborze i odwoływaniu, za zgodą przewodniczącego Komisji Europejskiej, wysokiego przedstawiciela Unii do spraw zagranicznych i polityki bezpieczeństwa (art. 18 ust. 1 TUE); wskazywaniu kandydata na przewodniczącego Komisji Europejskiej, po uwzględnieniu wyników wyborów do Parlamentu Europejskiego (art. 17 ust. 7 TUE), mianowaniu kolegium Komisji Europejskiej (art. 17 ust. 7 TUE), a także mianowaniu członków Zarządu EBC na zlecenie Rady i po konsultacji z Parlamentem Europejskim oraz Radą EBC (art. 283 ust. 2 TFUE). Wszystkie wspomniane wyżej uprawnienia nominacyjne Rada Europejska realizuje, stanowiąc większością kwalifikowaną ${ }^{12}$.

Ustanowienie urzędu przewodniczącego Rady Europejskiej należy do tych rozwiązań traktatowych, których wpływ na proces decyzyjny, jak również na funkcjonowanie Unii - podobnie jak utworzenie urzędu wysokiego przedstawiciela Unii do spraw zagranicznych i polityki bezpieczeństwa - trudno jest w tej chwili przewidzieć.

10 Traktat z Lizbony, op. cit., s. 29, 42, 46, 51, 56-59, 96.

11 Ibidem, s. 57-58.

12 Ibidem, s. 30, 34, 219. 
Zmiany te bowiem mogą mieć zarówno porządkujący wpływ na funkcjonowanie Unii, jak i prowadzić mogą do sporów kompetencyjnych pomiędzy przewodniczącym Rady Europejskiej, przewodniczącym Komisji Europejskiej, a także wysokim przedstawicielem Unii do spraw zagranicznych i polityki bezpieczeństwa. Spory kompetencyjne mogą powstawać także pomiędzy przewodniczącym Rady Europejskiej a szefami państw lub rządów pozostałych państw członkowskich Unii Europejskiej. Ustanowienie urzędu przewodniczącego Rady Europejskiej może także prowadzić do osłabienia metody wspólnotowej i pozycji samej Komisji Europejskiej w systemie instytucjonalnym Unii. Powstaje w związku z tym pytanie, czy szefowie państw lub rządów będą wspierać przewodniczącego Rady Europejskiej, czy też będą się mu sprzeciwiać i na przykład organizować posiedzenia na najwyższym szczeblu w ramach Rady ds. Ogólnych? Należy założyć, że jeżeli przewodniczący Rady Europejskiej będzie się cieszył autorytetem szefów państw lub rządów, to będzie znajdował w nich oparcie. Doprowadzi to do umocnienia Rady Europejskiej w systemie instytucjonalnym Unii Europejskiej, a także do wzmocnienia Unii jako całości. Jeżeli jednak będzie on słabym przewodniczącym, prawdopodobieństwo sporów kompetencyjnych będzie wzrastać, powstanie zagrożenie sparaliżowania działalności Rady Europejskiej, a nawet zagrożenie nawiązania wzmocnionej współpracy przez grupę niezadowolonych państw członkowskich $^{13}$.

\section{Rada}

Na mocy Traktatu lizbońskiego do TUE i TFUE wprowadzone zostaje pięć istotnych zmian w funkcjonowaniu Rady Unii Europejskiej, wzmacniających infrastrukture międzyrządową, ale paradoksalnie również metodę wspólnotową w Unii Europejskiej. Pierwsza z nich polega na ustaleniu nowej nazwy dla tej instytucji. Winna się ona odtąd nazywać: Rada. Istotą drugiej zmiany jest ustanowienie dwóch zasadniczych formacji Rady - Rady do Spraw Ogólnych i Rady do Spraw Zagranicznych (art. 16 ust. 6 TUE) $)^{14}$. Traktat dopuszcza możliwość powoływania przez Radę Europejską, większością kwalifikowaną, innych formacji Rady, co świadczy o zamiarze ograniczenia w przyszłości ilości tych formacji (art. 236 TFUE) ${ }^{15}$. Trzecią zmianą jest nowe określenie zasad pełnienia prezydencji w Unii. Traktat o Unii Europejskiej i załączona do Aktu Końcowego konferencji międzyrządowej 2007 r. deklaracja nr 9 postanawiają, iż prezydencję w poszczególnych formacjach Rady, z wyjątkiem Rady do Spraw Zagranicznych, sprawować będą na zasadzie równej rotacji przedstawiciele trzech państw członkowskich przez okres osiemnastu miesięcy, przy czym każdy z nich przez sześć miesięcy winien przewodniczyć wszystkim formacjom Rady. Natomiast przewodnictwo w Radzie do Spraw Zagranicznych ma na stałe pełnić wysoki przedstawiciel Unii do spraw zagranicznych i polityki bezpieczeństwa (art. 16 ust. 9 TUE, deklaracja nr 9) ${ }^{16}$.

13 Szerzej na ten temat por. J. J. Węc, Nowy model prezydencji, op. cit., s. 46-48.

14 Traktat z Lizbony, op. cit., s. 31-32.

15 Ibidem, s. 200.

16 Ibidem, s. 32; Deklaracja odnoszaca się do artykulu 16 ustęp 9 Traktatu o Unii Europejskiej, op. cit., s. 431-433. 
Czwarta zmiana polega na rozszerzeniu zakresu stosowania procedury podejmowania decyzji większością kwalifikowaną w Radzie na ponad czterdzieści nowych przypadków, co wskazuje na znaczące wzmocnienie metody wspólnotowej w procesie podejmowania decyzji. Głosowanie jednomyślne utrzymane zostaje natomiast zasadniczo w dziesięciu obszarach, odnoszących się pośrednio lub bezpośrednio do suwerenności lub interesów narodowych państw członkowskich, w szczególności zaś we wspólnej polityce zagranicznej i bezpieczeństwa, w polityce podatkowej, a także w procedurze uchwalania wieloletnich ram finansowych. Piąta niezwykle istotna zmiana sprowadza się do ustanowienia nowej procedury podejmowania decyzji większością kwalifikowaną w Radzie, a także rozciągnięcia po raz pierwszy jej reguł na Radę Europejską. W ślad za tym od 1 listopada 2014 r. większość kwalifikowaną będzie stanowić co najmniej 55\% członków Rady, jednak nie mniej niż piętnastu z nich, reprezentujących państwa członkowskie, których łączna liczba ludności stanowi co najmniej 65\% ludności Unii. Mniejszość blokująca musi obejmować co najmniej czterech członków Rady. W przeciwnym razie większość kwalifikowana nie zostanie osiaggnięta (art. 16 ust. 4 TUE). Traktat wprowadza także nową tzw. superkwalifikowaną większość głosów w przypadku, gdy Rada nie stanowi na wniosek Komisji Europejskiej lub wysokiego przedstawiciela Unii do spraw zagranicznych i polityki bezpieczeństwa. Wtedy większość kwalifikowaną ma stanowić co najmniej 72\% członków Rady reprezentujących państwa członkowskie, których łączna liczba ludności wynosi co najmniej 65\% ludności Unii (art. 238 ust. 2 TFUE). Te same zasady głosowania odnoszą się do Rady Europejskiej, gdy stanowi ona większością kwalifikowaną (art. 235 ust. 1 TFUE). Inaczej niż Traktat konstytucyjny, Traktat lizboński doprecyzowuje również zasady głosowania większością kwalifikowaną w przypadku, gdy nie wszyscy członkowie Rady biorą w nim udział. Jeżeli taki przypadek ma miejsce, to wówczas większość kwalifikowaną stanowi co najmniej 55\% członków Rady, reprezentujących uczestniczące w głosowaniu państwa członkowskie, których łączna liczba ludności stanowi co najmniej $65 \%$ ludności tychże państw. Mniejszość blokująca obejmuje natomiast co najmniej minimalną liczbę członków Rady, reprezentujących ponad 35\% ludności uczestniczących w głosowaniu państw członkowskich, plus jeden członek. W przeciwnym razie większość kwalifikowana nie zostaje osiąnnięta. Jeżeli natomiast Rada nie stanowi na wniosek Komisji Europejskiej lub wysokiego przedstawiciela Unii do spraw zagranicznych i polityki bezpieczeństwa, to wymaganą większość kwalifikowaną tworzy co najmniej $72 \%$ członków Rady, reprezentujących uczestniczące w głosowaniu państwa członkowskie, których łączna liczba ludności stanowi co najmniej 65\% ludności tychże państw (art. 238 ust. 3 TFUE) ${ }^{17}$.

$\mathrm{Z}$ drugiej strony protokół $\mathrm{nr} 36 \mathrm{w}$ sprawie postanowień przejściowych, załączony do TUE, TFUE i TEWEA, przewiduje, że do 31 października 2014 r. w odniesieniu do uchwał Rady Europejskiej i Rady, wymagających większości kwalifikowanej, obowiązywać będą postanowienia Traktatu nicejskiego. W związku z tym większość kwalifikowaną stanowić będzie co najmniej 255/345 głosów, przy czym każdy członek Rady Europejskiej lub Rady może zażądać sprawdzenia, czy państwa członkowskie

17 Traktat z Lizbony, op. cit., s. 31, 200-202. 
stanowiące tę większość kwalifikowaną reprezentują co najmniej 62\% ogółu ludności Unii. Jeżeli na mocy traktatów uchwały te winny być przyjęte na wniosek Komisji Europejskiej, to niezbędna jest dla ich przyjęcia zgoda większości członków Rady Europejskiej lub Rady, w przeciwnym zaś przypadku co najmniej 2/3 członków Rady Europejskiej lub Rady. Te same zasady obowiązują w przypadku, gdy nie wszyscy członkowie Rady biorą udział w głosowaniu (art. 3 ust. 3 protokołu nr 36). Natomiast między 1 listopada 2014 r. a 31 marca 2017 r. każdy członek Rady Europejskiej lub Rady będzie mógł zawsze zażąać, by uchwała wymagająca większości kwalifikowanej, została przyjęta zgodnie z tymi samymi postanowieniami Traktatu nicejskiego (art. 3 ust. 2 protokołu $\mathrm{nr} 36)^{18}$. Należy zwrócić uwagę na fakt, że przepisy zawarte w protokole nr 36 nie tylko utrzymują aż do 2017 r. dotychczasową pozycję Polski w unijnym procesie decyzyjnym, ale - i to wydaje się być istotne dla całej Unii Europejskiej - sprzyjają także elastycznemu przejściu do nowego mechanizmu podejmowania decyzji.

Ponadto deklaracja nr 7, załączona do Aktu Końcowego konferencji międzyrządowej 2007 r., zawiera projekt decyzji Rady, który przewiduje ustanowienie mechanizmu dodatkowych konsultacji, zbliżonego do tzw. mechanizmu z Joanniny z 29 marca $1994 \mathrm{r}$. (w wersji z 1 stycznia 1995 r.) ${ }^{19}$. W okresie przejściowym, czyli między 1 listopada 2014 r. a 31 marca 2017 r., członkowie Rady reprezentujący co najmniej 75\% ludności Unii lub co najmniej 75\% liczby państw członkowskich niezbędne do utworzenia mniejszości blokującej, będą mogli wyrazić swój sprzeciw wobec przyjęcia danego aktu prawnego przez Radę większością kwalifikowaną. Jeżeli tak się stanie, kwestia ta trafi pod obrady Rady, która winna w „rozsądnym terminie i bez uszczerbku dla wiążących terminów określonych przez prawo Unii, osiągnąc zadowalające rozwiązanie wątpliwości" podniesionych przez wspomnianych członków Rady. W tym celu przewodniczący Rady, wspierany przez Komisję Europejską i z poszanowaniem regulaminu Rady, powinien podjać „wszelkie inicjatywy, aby ułatwić stworzenie szerszej podstawy do osiagnięcia porozumienia w Radzie". W wykonaniu tego zadania winni

18 Protokół w sprawie postanowień przejściowych, w: Traktat z Lizbony, op. cit., s. 410-412.

19 Kompromis z Joanniny (Grecja) ustanowiony został na mocy decyzji sui generis Rady Unii Europejskiej podjętej 29 marca 1994 r. w związku z planowanym przyjęciem do Unii Europejskiej Austrii, Szwecji, Finlandii i Norwegii. Stanowił on, że jeżeli członkowie Rady posiadający łącznie od 23 do 26 głosów oświadczą, iż zamierzają się sprzeciwić decyzji Rady, dla której wymagana jest większość kwalifikowana, to Rada uczyni wszystko, co leży w granicach jej uprawnień, aby w rozsądnym terminie i bez uszczerbku dla obowiązujących ograniczeń czasowych określonych przez traktaty i wynikające z nich prawo (np. przez art. 189 b i art. 189 c - obecnie art. 251 do 252 TWE) znaleźć zadawalające rozwiązanie, które może być przyjęte większością co najmniej 68 głosów. W tym czasie przewodniczący Rady wspierany przez Komisję z poszanowaniem regulaminu Rady podejmie wszelkie inicjatywy, aby umożliwić stworzenie szerszej podstawy dla osiagnięcia porozumienia w Radzie. Członkowie Rady udzielą mu wsparcia w wykonaniu tego zadania. 1 stycznia 1995 r. w związku z tym, że Norwegia ostatecznie nie przystapiła do Unii wspomniana decyzja Rady została zmieniona w ten sposób, że liczby 26 i 68 zostały zastapione przez liczby 25 i 65. Istota kompromisu z Joanniny polegała na tym, że de facto utrzymywał on mniejszość blokującą na poziomie obowiązującym przed czwartym rozszerzeniem Unii. Por.: Council Decision of 29 March 1994 concerning the taking of Decision by qualified majority by the Council, Official Journal C, 1994, nr 105, s. 1; Council Decision of 1 January 1995 amending the Council Decision of 29 March 1994 concerning the taking of decisions by qualified majority by the Council, Official Journal C, 1995, nr 1, s. 1. 
go również wspierać inni członkowie Rady. Od 1 kwietnia 2017 r. mechanizm dodatkowych konsultacji ma być łatwiejszy do uruchomienia. Obniżone zostaną bowiem wówczas z $75 \%$ do $55 \%$ obydwa obowiązujące w nim progi, odpowiednio dla liczby ludności i dla liczby państw członkowskich, niezbędnej do utworzenia mniejszości blokującej (deklaracja $\mathrm{nr} 7)^{20}$. Z drugiej strony jednak protokół nr 9, załączony do TUE i TFUE, przewiduje możliwość zmiany lub uchylenia tego mechanizmu jednomyślną decyzją Rady Europejskiej ${ }^{21}$.

Nowa definicja większości kwalifikowanej najbardziej wzmacnia pozycję państw o największej liczbie ludności w procedurze podejmowania decyzji w Radzie i Radzie Europejskiej. Polska i Hiszpania, które najwięcej zyskały na zmianie systemu ważenia głosów ustanowionego przez Traktat nicejski (31\% wagi), tracą w jej wyniku niemal cały ten zysk. Wszelako z punktu widzenia możliwości zawiązywania mniejszości blokującej mechanizm dodatkowych konsultacji jest dla obu tych państw korzystny. W przypadku Polski udział w takiej mniejszości (7,91\% w Unii dwudziestu siedmiu państw) jest nawet porównywalny z udziałem określonym w Traktacie nicejskim ${ }^{22}$. Należy jednak podkreślić, że mechanizm dodatkowych konsultacji w jeszcze większym stopniu niż w przypadku Polski i Hiszpanii zwiększa możliwości tworzenia mniejszości blokującej przez największe demograficznie państwa członkowskie, jak RFN i Francja, które dzięki niemu mogą nawet same blokować podejmowanie decyzji ${ }^{23}$. Warto zwrócić także uwagę na fakt, że w dotychczasowej praktyce państwa członkowskie niezwykle rzadko odwoływały się do wspomnianego wyżej mechanizmu z Joanniny. Jeżeli miałoby się to potwierdzić w przypadku przewidywanego w Traktacie lizbońskim mechanizmu dodatkowych konsultacji, to należy stwierdzić, że ma on głównie znaczenie polityczne, albowiem nakłada na państwa członkowskie zobowiązanie, aby w miarę możliwości państwa sprzeciwiające się podjęciu danej decyzji nie były przegłosowywane tak długo, jak długo możliwe jest znalezienie kompromisowego rozwiązania.

\section{Komisja Europejska}

Traktat lizboński, wprowadzając zmiany do TUE i TFUE, wzmacnia kompetencje Komisji Europejskiej oraz jej przewodniczącego, a także wprowadza istotne modyfika-

20 Deklaracja odnoszaca się do artykutu 16 ustęp 2 Traktatu o Unii Europejskiej i artykułu 238 ustęp 2 Traktatu o funkcjonowaniu Unii Europejskiej w okresie między 1 listopada 2014 roku a 31 marca 2017 roku i od 1 kwietnia 2017 roku, w: Traktat z Lizbony, op. cit., s. 428-431.

${ }_{21}$ Protokót w sprawie decyzji Rady odnoszacej się do wykonania artykułu 16 ustęp 4 Traktatu o Unii Europejskiej i artykulu 238 ustęp 2 Traktatu o funkcjonowaniu Unii Europejskiej w okresie między 1 listopada 2014 roku a 31 marca 2017 roku i od 1 kwietnia 2017 roku, w: Traktat z Lizbony, op. cit., s. 356 .

${ }_{22}$ Informacja dla Sejmu i Senatu o udziale Rzeczypospolitej w pracach Unii Europejskiej w maju i czerwcu 2004 r. (od dnia przystapienia RP do UE do końca prezydencji irlandzkiej). Dokumenty i materiały źródłowe, http:/www2.ukie.gov.pl/, s. 11.

${ }^{23}$ Krytyczną ocenę definicji większości kwalifikowanej, ustanowionej już w Traktacie konstytucyjnym, por. R. Trzaskowski, Dynamika reformy systemu podejmowania decyzji w Unii Europejskiej, Warszawa 2005, s. 350-355. 
cje w składzie Komisji. Umocnienie uprawnień Komisji Europejskiej, wzmacniające infrastrukturę ponadnarodową w Unii Europejskiej, polega na zwiększeniu jej roli w procedurze uchwalania rocznego budżetu, procedurze wielostronnego nadzoru oraz procedurze unikania nadmiernego deficytu. Oznacza to istotne wzmocnienie metody wspólnotowej w przyszłej Unii Europejskiej. W procedurze uchwalania rocznego budżetu Komisja Europejska uzyskuje po raz pierwszy pełne prawo do inicjatywy prawodawczej, czyli prawo do opracowania projektu budżetu, a nie jak dotychczas prawo do przygotowania wstępnego projektu budżetu. Może ona również zmieniać projekt budżetu w czasie trwania procedury aż do czasu powołania komitetu pojednawczego (art. 314 ust. 2 TFUE) $)^{24}$. W procedurze wielostronnego nadzoru Komisja Europejska uzyskuje prawo wystosowywania tzw. wczesnego ostrzeżenia do państwa członkowskiego (dotychczas było to jedynie zalecenie), którego polityka gospodarcza nie jest zgodna z ogólnymi wytycznymi polityki gospodarczej ustalonymi przez Radę lub zagraża prawidłowemu funkcjonowaniu Unii Gospodarczej i Walutowej (art. 121 ust. 3-4 TFUE $)^{25}$. W procedurze unikania nadmiernego deficytu Komisja Europejska nabywa prawo występowania do Rady z formalną propozycja, a nie jak dotąd z zaleceniem, podjęcia przez Radę decyzji o zaistnieniu nadmiernego deficytu w danym państwie członkowskim. Oznacza to, że jeżeli Rada chciałaby zmienić propozycję Komisji Europejskiej, zaś ta ostatnia byłaby temu przeciwna, to musiałaby podjąć w tej sprawie jednomyślną decyzję. W dalszej fazie tej samej procedury Rada może kierować do takiego państwa zalecenie zlikwidowania nadmiernego deficytu w określonym terminie, ale również tylko na podstawie wcześniejszego zalecenia Komisji, czego nie przewidywały dotychczasowe regulacje (art. 126 ust. 6-7 TFUE) ${ }^{26}$.

Niezwykle istotne znacznie ma także wzmocnienie pozycji przewodniczącego Komisji Europejskiej, czego wyrazem jest wspomniane wyżej prawo do udzielania przez niego zgody na mianowanie i odwoływanie, a nawet zażądanie odwołania przez Radę Europejską wysokiego przedstawiciela Unii do spraw zagranicznych i polityki bezpieczeństwa (art. 17 ust. 6 , art. 18 ust. 1 TUE) ${ }^{27}$. Traktat przyznaje również przewodniczącemu Komisji Europejskiej nowe uprawnienia w procedurze powoływania kolegium Komisji. W pierwszej fazie (wyznaczanie przewodniczącego) Rada Europejska, uwzględniając wybory do Parlamentu Europejskiego i po przeprowadzeniu stosownych konsultacji, w trybie większości kwalifikowanej, przedstawia Parlamentowi swojego kandydata na przewodniczącego Komisji. W drugiej fazie (wybieranie przewodniczącego) kandydat ten jest wybierany przez Parlament Europejski większością głosów członków wchodzących w jego skład. Jeżeli nie uzyska on wymaganej większości, Rada Europejska, stanowiąc większością kwalifikowaną, w terminie miesiąca przedstawia nowego kandydata, który jest wybierany przez Parlament Europejski zgodnie z tą samą procedurą. W trzeciej fazie (wyznaczenie pozostałych członków kolegium) Rada, za wspólnym porozumieniem z wybranym przewodniczącym Komisji Europejskiej, „na podstawie sugestii zgłaszanych przez Państwa Członkowskie”,

\footnotetext{
24 Traktat z Lizbony, op. cit., s. 240.

25 Ibidem, s. 128-129.

26 Ibidem, s. 131-132.

27 Ibidem, s. 33-34.
} 
przyjmuje listę pozostałych osób, które proponuje mianować na członków Komisji. W czwartej fazie (zatwierdzenie całego kolegium) przewodniczący, wysoki przedstawiciel Unii do spraw zagranicznych i polityki bezpieczeństwa oraz pozostali członkowie Komisji Europejskiej podlegają kolegialnie zatwierdzeniu przez Parlament Europejski. Natomiast w piątej fazie (mianowanie całego kolegium) Rada Europejska na podstawie takiego zatwierdzenia, stanowiąc większością kwalifikowaną, mianuje cały skład Komisji Europejskiej (art. 17 ust. 7 TUE) $)^{28}$.

Traktat wprowadza także istotne zmiany w składzie Komisji Europejskiej. I tak, w skład pierwszej Komisji Europejskiej, mianowanej między datą wejścia w życie Traktatu lizbońskiego a dniem 31 października 2014 r. ma wchodzić po jednym przedstawicielu każdego z państw członkowskich, w tym jej przewodniczący i wysoki przedstawiciel Unii do spraw zagranicznych i polityki bezpieczeństwa jako jeden z wiceprzewodniczących Komisji. Natomiast od 1 listopada 2014 r. Komisja winna się składać z liczby członków odpowiadającej 2/3 ogólnej liczby państw, łącznie z jej przewodniczącym i wysokim przedstawicielem Unii do spraw zagranicznych i polityki bezpieczeństwa, chyba że Rada Europejska, stanowiąc jednomyślnie, podejmie decyzję o zmianie tej liczby (art. 17 ust. 4-5 TUE) ${ }^{29}$. Przepis Traktatu lizbońskiego o ograniczeniu składu Komisji Europejskiej do 2/3 ogólnej liczby państw członkowskich zostanie jednak zrewidowany na wyraźne życzenie Irlandii, jeżeli powtórzone referendum w tym kraju zakończy się pozytywnie i Traktat wejdzie w życie ${ }^{30}$. Polityczną decyzję w tej sprawie przyjęła w dniach 12-13 grudnia 2008 r. Rada Europejska podczas swojego posiedzenia w Brukseli. Zaleciła ona wówczas, aby „o ile Traktat z Lizbony wejdzie w życie - podjęto zgodnie z niezbędnymi procedurami prawnymi, decyzję stanowiąca, że w skład Komisji nadal będzie wchodzić jeden obywatel z każdego państwa członkowskiego" ${ }^{\text {31 }}$.

28 Ibidem, s. 34.

29 Ibidem, s. 33

3012 czerwca 2008 r. społeczeństwo Irlandii odrzuciło Traktat w referendum większością 53,4\% głosów. Natomiast w powtórzonym referendum przeprowadzonym 2 października 2009 r. mieszkańcy Irlandii zaakceptowali traktat większością 67,1\% głosów.

31 Rada Europejska podjęła również decyzję o zapewnieniu niezbędnych gwarancji prawnych wobec Irlandii w następujących sprawach: po pierwsze, ,żadne postanowienie Traktatu z Lizbony nie będzie miało żadnego wpływu w odniesieniu do żadnego państwa na zakres ani wykonywanie kompetencji Unii w dziedzinie opodatkowania”; po drugie, ,Traktat z Lizbony nie będzie miał wpływu na politykę bezpieczeństwa i obrony państw członkowskich, w tym na tradycyjną irlandzką politykę neutralności, ani na zobowiązania większości pozostałych państw członkowskich”; po trzecie, „fakt przyznania w Traktacie z Lizbony prawnego statusu Karcie praw podstawowych Unii Europejskiej ani żadne postanowienia tego Traktatu odnoszące się do wymiaru sprawiedliwości i spraw wewnętrznych w żaden sposób nie narusza żadnych postanowień konstytucji Irlandii dotyczących prawa do życia, edukacji i rodziny". Ponadto potwierdzone zostanie duże znaczenie, jakie nadaje się postępowi społecznemu i ochronie praw pracowniczych, usługom publicznym jako niezbędnemu instrumentowi zapewniającemu spójność społeczną i regionalną, odpowiedzialności państw członkowskich za świadczenie usług edukacyjnych i zdrowotnych, a także zasadniczej roli i szerokiemu zakresowi uprawnień organów krajowych, regionalnych i lokalnych w zakresie świadczenia, zlecania i organizowania usług niemających charakteru gospodarczego, świadczonych w interesie ogólnym, na które nie będą miały wpływu żadne postanowienia Traktatu z Lizbony, w tym postanowienia dotyczące wspólnej polityki handlowej, por. Posiedzenie Rady Europejskiej w dniach 12-13 grudnia 2008 r. w Brukseli. Konkluzje Prezydencji, http://www.eu2008, s. 2, 12 (załącznik I). 
Traktat lizboński, wprowadzając zmiany do TUE i TFUE, porządkuje również dotychczasowe uprawnienia Komisji Europejskiej, dzieląc je na funkcje prawodawcze, kontrolne, wykonawcze i międzynarodowe. Komisja Europejska posiada wyłączne prawo do inicjatywy prawodawczej w obszarze wspólnotowym. Czuwa nad stosowaniem traktatów i środków przyjmowanych przez instytucje na ich podstawie. Winna nadzorować stosowanie prawa Unii, pod kontrolą Trybunału Sprawiedliwości Unii Europejskiej. Powinna wykonywać budżet i zarządzać programami. Ma również wypełniać funkcje koordynacyjne, wykonawcze i zarządzające, zgodnie z warunkami przewidzianymi w traktatach, a także zapewniać reprezentację Unii Europejskiej na zewnątrz we wszystkich sprawach, z wyjątkiem wspólnej polityki zagranicznej i bezpieczeństwa oraz innych przypadków przewidzianych w traktatach. W końcu także winna ona podejmować inicjatywy dotyczące rocznego i wieloletniego programowania działalności Unii w celu osiagnięcia porozumień międzyinstytucjonalnych (art. 17 ust. 1-2 TUE) ${ }^{32}$. Ponadto Traktat lizboński po raz pierwszy wprowadza do TUE, TFUE i TEWEA nazwę „Komisja Europejska” - w miejsce występującego w nich dotąd określenia „Komisja” (art. 13 ust. 1 TUE) ${ }^{33}$.

Należy podkreślić, że w tej chwili nie jest jasne, w jaki sposób na funkcjonowanie Unii Europejskiej wpłynie uzależnienie wyboru przewodniczącego Komisji Europejskiej od układu sił politycznych w Parlamencie Europejskim. Zmiana ta wzmacnia bowiem legitymację demokratyczną Komisji Europejskiej, ponieważ na wybór jej przewodniczącego bezpośredni wpływ uzyskuje Parlament Europejski. Z drugiej strony jednak może to także prowadzić do upolitycznienia Komisji Europejskiej, a tym samym zagrozić metodzie wspólnotowej. Szczególnie niekorzystne mogłoby być upolitycznienie jej funkcji w zakresie inicjatywy prawodawczej oraz funkcji strażnika traktatów. Również ustanowienie urzędu przewodniczącego Rady Europejskiej może prowadzić do osłabienia metody wspólnotowej i pozycji samej Komisji Europejskiej w systemie instytucjonalnym Unii.

\section{Parlament Europejski}

Traktat lizboński wyznacza ważną cezurę w dotychczasowej działalności Parlamentu Europejskiego, choć nie likwiduje deficytu demokracji, który chyba w największym stopniu dotyczy właśnie funkcjonowania tej instytucji. Wprowadzając zmiany do TUE i TFUE, Traktat ten umacnia rolę Parlamentu Europejskiego w systemie instytucjonalnym Unii Europejskiej, co jest następstwem uznania procedury współdecydowania za zwykłą procedurę prawodawczą, rozszerzenia materialnego zakresu jej zastosowania, nadania Parlamentowi prawa do wybierania przewodniczącego Komisji Europejskiej, a także zwiększenia uprawnień Parlamentu w następujących procedurach: uchwalania rocznego budżetu, wielostronnego nadzoru, wieloletnich ram finansowych, zwykłej i uproszczonej rewizji traktatów oraz dobrowolnego wystapienia z Unii. Wszystkie te zmiany wzmacniają infrastrukturę ponadnarodową w Unii Europejskiej. W efekcie sa-

32 Traktat z Lizbony, op. cit., s. 32.

33 Ibidem, s. 28 
mego tylko przekształcenia procedury współdecydowania w zwykłą procedurę prawodawczą oraz rozszerzenia zakresu jej zastosowania ok. 95\% aktów prawodawczych winno być w przyszłości przyjmowane łącznie przez Parlament Europejski i Radę.

Wzmocnienie pozycji Parlamentu Europejskiego w procedurze uchwalania rocznego budżetu Unii Europejskiej wynika ze zniesienia podziału wydatków budżetowych na obligatoryjne i nieobligatoryjne, a także wprowadzenia do procedury budżetowej postępowania rozjemczego, podobnego do tego, które jest stosowane w zwykłej procedurze prawodawczej. Postępowanie to przyznaje jednak Parlamentowi Europejskiemu dodatkowo prawo do potwierdzenia własnych poprawek, po uprzednim przyjęciu wspólnego projektu przez komitet pojednawczy, czego zwykła procedura prawodawcza jednak nie przewiduje. Oznacza to, że po pozytywnym zakończeniu postępowania rozjemczego, do uchwalenia budżetu niezbędna jest zgoda Parlamentu Europejskiego i Rady, podobnie jak w zwykłej procedurze prawodawczej, ale z drugiej strony, w przypadku odrzucenia przez Radę wspólnego projektu uzgodnionego przez komitet pojednawczy, Parlament może doprowadzić do uchwalenia budżetu na podstawie wszystkich lub części swoich poprawek (art. 314 ust. 7 lit. a-d TFUE). Pozycję Parlamentu Europejskiego, ale także demokratyczną kontrolę nad wykonaniem budżetu, wzmacnia ponadto postanowienie Traktatu zobowiązujące Komisję Europejską do przedkładania Parlamentowi i Radzie sprawozdania oceniającego finanse Unii Europejskiej przed rozpoczęciem parlamentarnego postępowania w sprawie uchwalenia absolutorium Z realizacji budżetu (art. 318 TFUE) ${ }^{34}$. Zwiększenie uprawnień Parlamentu Europejskiego w procedurze wielostronnego nadzoru polega natomiast na tym, że przy uchwalaniu aktów prawnych dotyczących wielostronnego nadzoru ma obowiązywać zwykła procedura prawodawcza, a nie jak dotąd procedura współpracy (art. 121 ust. 3-4 TFUE) $)^{35}$.

Traktat stwarza także po raz pierwszy podstawy traktatowe dla procedury uchwalania, na okres co najmniej pięciu lat, wieloletnich ram finansowych (zwanych dotąd perspektywą finansową), zwiększając w niej równocześnie uprawnienia Parlamentu Europejskiego. Ma on wydawać zgodę, stanowiąc większością głosów wchodzących w jego skład członków, na uchwalenie przez Radę, w trybie jednomyślnym i zgodnie ze specjalną procedurą prawodawczą, rozporządzenia określającego wieloletnie ramy finansowe. Ponadto wraz z Radą i Komisją Europejską jest on zobowiązany, aby w czasie całej procedury prowadzącej do przyjęcia wieloletnich ram finansowych podejmować wszelkie środki, niezbędne do pomyślnego jej zakończenia (art. 312 ust. 1-2, 5 TFUE) ${ }^{36}$. We wspomnianych wyżej zwykłej i uproszczonej procedurze rewizji traktatów Parlament Europejski uzyskuje - oprócz, jak dotąd, Komisji Europejskiej i rządów państw członkowskich - prawo do inicjatywy w zakresie ustanowienia zmian w traktatach, przedkładanych Radzie (procedura zwykła), albo rewizji wszystkich lub niektórych postanowień Części trzeciej TFUE, dotyczących polityk i działań wewnętrznych Unii, przedkładanych Radzie Europejskiej (procedura uproszczona). Parlamentowi Europejskiemu przyznane zostaje także prawo do konsultowania go (obie procedury) - podobnie jak i Komisji - przez Radę Europejską w sytuacji, gdy propozy-

34 Ibidem, s. 241, 243-244.

35 Ibidem, s. 128-129.

${ }^{36}$ Ibidem, s. 239. 
cja zmiany zostanie zgłoszona. Ponadto Parlament Europejski uzyskuje prawo do wyrażania zgody na decyzję Rady Europejskiej o niezwoływaniu Konwentu, jeżeli zakres proponowanych zmian nie uzasadnia jego zwołania. W konsekwencji prowadzi to bezpośrednio do określenia mandatu i zwołania konferencji międzyrządowej przez Radę Europejską (art. 48 ust. 2-3, 6 TUE) ${ }^{37}$. Natomiast w procedurze dobrowolnego wystąpienia danego państwa członkowskiego z Unii Europejskiej Parlament uzyskuje prawo do wyrażania zgody na zawarcie przez Radę, stanowiącą większością kwalifikowaną, umowy z takim państwem, określającej warunki jego wystąpienia (art. 50 ust. 2 TUE) ${ }^{38}$.

Traktat lizboński ponownie określa także liczbę deputowanych do Parlamentu Europejskiego, stanowiąc, że nie może ona przekraczać siedmiuset pięćdziesięciu osób, nie licząc przewodniczącego. Reprezentacja obywateli w Parlamencie Europejskim ma mieć również, tak jak dotychczas, charakter degresywnie proporcjonalny, z minimalnym progiem sześciu deputowanych i maksymalnym progiem dziewięćdziesięciu sześciu deputowanych na państwo członkowskie. Decyzję określającą szczegółowy podział mandatów w Parlamencie Europejskim pomiędzy poszczególne państwa członkowskie podejmuje Rada Europejska, stanowiąc jednomyślnie, z inicjatywy Parlamentu i po uzyskaniu jego zgody, ale także z poszanowaniem wspomnianych zasad (art. 14 ust. 2 TUE) ${ }^{39}$.

\section{Trybunal Sprawiedliwości Unii Europejskiej}

Traktat lizboński, wprowadzając zmiany do TUE i TFUE, nie ustanawia zbyt wielu istotnych zmian w funkcjonowaniu Trybunału Sprawiedliwości. Najważniejsze z nich dotyczą nazewnictwa, procedury powoływania i rozszerzenia kompetencji Trybunału, modyfikacji przepisów umożliwiających ustanawianie sądów wyspecjalizowanych, a także - czego nie przewidywał Traktat konstytucyjny - określenia nowego składu rzeczników generalnych. Jeśli chodzi o nazewnictwo, to Traktat stanowi, że instytucja ta nosi odtąd nazwę: Trybunał Sprawiedliwości Unii Europejskiej, który obejmuje Trybunał Sprawiedliwości, Sąd i sądy wyspecjalizowane (art. 19 ust. 1 TUE) ${ }^{40}$. Zmiana w procedurze powoływania Trybunału Sprawiedliwości i Sądu polega na tym, że rządy państw członkowskich przed mianowaniem sędziów i rzeczników generalnych w Trybunale Sprawiedliwości i Sądzie mają konsultować nowo ustanowiony Komitet, złożony z siedmiu osobistości, w tym byłych sędziów Trybunału Sprawiedliwości i Sądu, członków krajowych sądów najwyższych i prawników o uznanej kompetencji, przy czym jedną z tych kandydatur proponuje Parlament Europejski. Członków Komitetu ma mianować Rada na wniosek prezesa Trybunału Sprawiedliwości (art. 255 TFUE) ${ }^{41}$.

Rozszerzenie kompetencji Trybunału Sprawiedliwości, wzmacniające infrastrukturę ponadnarodową w Unii Europejskiej, polega na objęciu po raz pierwszy jego jurys-

\footnotetext{
37 Ibidem, s. 56-57.

38 Ibidem, s. 58.

39 Ibidem, s. 29.

40 Ibidem, s. 35.

41 Ibidem, s. 208.
} 
dykcją Rady Europejskiej w zakresie sprawdzania legalności jej aktów, zmierzających do wywarcia skutków prawnych wobec podmiotów trzecich, a także organów i jednostek organizacyjnych Unii, które zmierzają do wywarcia skutków prawnych wobec osób trzecich (art. 263 TFUE). Trybunał Sprawiedliwości uzyskuje również prawo do rozpatrywania skarg na zaniechanie działania przez Radę Europejską oraz organy i jednostki organizacyjne Unii (art. 265 TFUE). Zwiększeniu ulega ponadto efektywność mechanizmu stosowania sankcji w przypadku nierespektowania przez państwa członkowskie orzeczeń Trybunału (art. 260 ust. 1-2 TFUE) ${ }^{42}$. Z drugiej strony, nadal ograniczone są jednak uprawnienia Trybunału Sprawiedliwości we wspólnej polityce zagranicznej i bezpieczeństwa oraz w przestrzeni wolności, bezpieczeństwa i sprawiedliwości. Generalnie rzecz biorąc, Trybunał Sprawiedliwości nie jest właściwy do orzekania w sprawach wspólnej polityki zagranicznej i bezpieczeństwa oraz wspólnej polityki bezpieczeństwa i obrony ani w zakresie aktów przyjętych na ich podstawie (art. 275 TFUE). Traktat przyznaje mu jednak kompetencje do sprawowania kontroli nad tym, aby realizacja wspólnej polityki zagranicznej i bezpieczeństwa nie naruszała stosowania procedur oraz zakresu uprawnień instytucji przewidzianych w traktatach do wykonywania kompetencji wyłącznych Unii, kompetencji dzielonych, kompetencji w zakresie koordynacji polityk gospodarczych i zatrudnienia oraz kompetencji wspierających, koordynujących i uzupełniających działania państw członkowskich. Z drugiej strony, Trybunał ma także sprawować kontrolę nad nienaruszaniem stosowania procedur oraz zakresu uprawnień instytucji przewidzianych w traktatach do wykonywania kompetencji Unii Europejskiej we wspólnej polityce zagranicznej i bezpieczeństwa (art. 275 TFUE, art. 40 TUE). Ponadto uzyskuje on uprawnienia do kontroli legalności decyzji, przewidujących środki ograniczające, stosowane wobec osób fizycznych i prawnych, przyjętych przez Radę w sprawie wspólnej polityki zagranicznej i bezpieczeństwa (art. 275 TFUE) ${ }^{43}$. Natomiast w odniesieniu do przestrzeni wolności, bezpieczeństwa i sprawiedliwości Traktat wyraźnie stwierdza, że Trybunał Sprawiedliwości nie jest właściwy do sprawowania kontroli ważności lub proporcjonalności działań policji albo innych organów ścigania w danym państwie członkowskim ani do orzekania w sprawie wykonywania przez państwa członkowskie obowiązków dotyczących utrzymania porządku publicznego i ochrony bezpieczeństwa wewnętrznego (art. III-276 TFUE) ${ }^{44}$.

Na mocy Traktatu lizbońskiego do TFUE wprowadzone zostają nowe przepisy w sprawie powoływania sądów wyspecjalizowanych. Mają być one ustanawiane w drodze rozporządzeń przez Parlament Europejski i Radę, stanowiące zgodnie ze zwykłą procedurą prawodawczą (a nie jak dotąd na mocy jednomyślnej decyzji Rady), na wniosek Komisji Europejskiej i po konsultacji z Trybunałem Sprawiedliwości albo na wniosek Trybunału Sprawiedliwości i po konsultacji z Komisją Europejską (art. 257 TFUE) $)^{45}$. Pierwszym sądem wyspecjalizowanym, utworzonym 12 grudnia 2005 r., jest

42 Ibidem, s. 211-213.

43 Ibidem, s. 49, 217.

44 Ibidem, s. 217.

45 Ibidem, s. 209. 
Sąd do spraw Służby Publicznej Unii Europejskiej. Rozstrzyga on spory pomiędzy Unią Europejską i jej pracownikami na mocy art. 270 TFUE $^{46}$.

Jeśli chodzi o nowy skład rzeczników generalnych, to na podstawie deklaracji nr 38, załączonej do Aktu Końcowego konferencji międzyrządowej z 2007 r., zwiększona zostaje z ośmiu do jedenastu ich liczba, przy czym Polska - obok, jak dotychczas, RFN, Francji, Wielkiej Brytanii, Włoch i Hiszpanii - uzyskuje stałego rzecznika generalnego i nie będzie już uczestniczyć w systemie rotacji, a tym samym obowiązujący system rotacji będzie obejmował pięciu rzeczników generalnych zamiast trzech ${ }^{47}$.

\section{Trybunal Obrachunkowy}

Prezentowany Traktat niewiele zmienia w dotychczasowej działalności Trybunału Obrachunkowego. Jedną z istotniejszych zmian jest to, że Trybunał Obrachunkowy uzyskuje prawo do powoływania „,wewnętrznych izb” w celu przyjmowania pewnych kategorii sprawozdań lub opinii na warunkach określonych w jego regulaminie wewnętrznym (art. 287 ust. 4 TFUE) ${ }^{48}$.

\section{Organy Unii Gospodarczej i Walutowej}

Na mocy Traktatu lizbońskiego do TUE i TFUE wprowadzonych zostaje sześć istotnych zmian w systemie instytucjonalnym Unii Gospodarczej i Walutowej. Należy podkreślić, że wszystkie zmiany dotyczące Europejskiego Banku Centralnego wzmacniają infrastrukturę ponadnarodową, zaś modyfikacje odnoszące się do Eurogrupy umacniają infrastrukturę międzyrządową w Unii Europejskiej. I tak, Traktat ten nadaje Europejskiemu Bankowi Centralnemu status instytucji Unii Europejskiej. Jednak w odróżnieniu od projektu Konwentu i samego Traktatu konstytucyjnego Europejski Bank Centralny, podobnie jak Trybunał Obrachunkowy, włączony zostaje na mocy prezentowanego Traktatu do tzw. ram instytucjonalnych, a tym samym do instytucji o charakterze politycznym Unii (art. 13 ust. 1 TUE) ${ }^{49}$. Traktat lizboński wprowadza również, i to jest druga zmiana, pojęcie Eurosystemu, obejmującego EBC i banki centralne państw należących do strefy euro (art. 282 ust. 1 TFUE) ${ }^{50}$. Dotychczas nazwa ta była używana nieoficjalnie i również nie znajdowała się w projekcie Konwentu, ale znalazła się w Traktacie konstytucyjnym. Trzecią zmianą jest sprecyzowanie warunków, na jakich

46 Protokół w sprawie Statutu Trybunału Sprawiedliwości Unii Europejskiej. Załqcznik I (Sąd do spraw Stużby Publicznej Unii Europejskiej), w: Traktat z Lizbony, op. cit., s. 293-298; Decyzja Rady $z$ dnia 2 listopada 2004 r. ustanawiajaca Sad do spraw Slużby Publicznej Unii Europejskiej, Dziennik Urzędowy Unii Europejskiej L, 2004, nr 333, s. 7-11.

47 Deklaracja odnoszaca się do artykulu 252 Traktatu o funkcjonowaniu Unii Europejskiej w sprawie liczby rzeczników generalnych w Trybunale Sprawiedliwości, w: Traktat z Lizbony, op. cit., s. 443.

\footnotetext{
48 Traktat z Lizbony, op. cit., s. 222.

49 Ibidem, s. 28.

50 Ibidem, s. 218.
} 
winien być sprawdzany poziom trwałej konwergencji osiagnięty przez państwa objęte derogacją. Ma tego dokonywać Komisja Europejska i EBC w formie sprawozdań, przesyłanych Radzie co najmniej co dwa lata lub na wniosek państwa członkowskiego objętego derogacją (art. 140 ust. 1 TFUE) ${ }^{51}$. Sprawozdania Komisji Europejskiej i EBC, inaczej niż dotychczas, nie muszą brać pod uwagę stanu rozwoju euro, co oznacza, że kondycja tej waluty nie będzie miała wpływu na przyjęcie do strefy euro nowych państw członkowskich.

Na mocy art. 137 TFUE i protokołu nr 14, załączonego do TUE i TFUE, usankcjonowana zostaje, i to jest czwarta zmiana, działalność Eurogrupy, złożonej z ministrów państw członkowskich strefy euro. Mają oni się zbierać na nieformalnych spotkaniach i w miarę potrzeby ,w celu omówienia spraw związanych ze szczególnymi obowiązkami, jakie na nich ciążą w związku z jedną walutą". W posiedzeniach tych ma także uczestniczyć przedstawiciel Komisji Europejskiej, zaś reprezentant EBC winien być na nie zapraszany. Spotkania takie powinny być przygotowywane przez przedstawicieli ministrów finansów państw członkowskich, należących do strefy euro, a także przez reprezentanta Komisji Europejskiej (art. 1 protokołu). Pracami Eurogrupy ma kierować przewodniczący wybierany przez jej członków większością głosów na okres dwóch i pół roku (art. 2 protokołu) ${ }^{52}$. Prezydencja w Eurogrupie ma zatem trwać tak długo, jak kadencja przewodniczącego Rady Europejskiej, co znacznie wzmacnia pozycję tego organu w systemie instytucjonalnym Unii Gospodarczej i Walutowej. Nadanie statusu traktatowego Eurogrupie wydaje się zrozumiałe również z tego powodu, że Rada ds. Gospodarki i Finansów po rozszerzeniu Unii Europejskiej w latach 2004 i 2007 stawała się formacją o wiele mniej odpowiednią do podejmowania decyzji w sprawach wspólnej waluty ze względu na dużą grupę państw członkowskich Unii Europejskiej nienależących do strefy euro.

Piąta zmiana polega na istotnym rozszerzeniu kompetencji Eurogrupy. Przyznano jej prawo do uchwalania zaleceń w sprawie przyjęcia nowego członka do strefy euro, stwarzając tym samym dodatkowy szczebel decyzyjny w tej procedurze. Zalecenie takie ma być przyjmowane większością kwalifikowaną w ciągu sześciu miesięcy od dnia otrzymania przez Radę wniosku Komisji Europejskiej w tej sprawie. Natomiast samą decyzję dotyczącą uchylenia derogacji wobec danego państwa członkowskiego ma podejmować Rada, stanowiąc większością kwalifikowaną, na wniosek Komisji Europejskiej, po konsultacji z Parlamentem Europejskim i dyskusji na forum Rady Europejskiej (art. 140 ust. 2 TFUE) $)^{53}$. Wszelako Traktat lizboński nie precyzuje, co się stanie w sytuacji, gdy Eurogrupa sprzeciwi się przyjęciu do strefy euro nowych państw członkowskich. Ponadto Eurogrupa uzyskuje wyłączne prawo do podejmowania, na wniosek Komisji Europejskiej, decyzji ustanawiających wspólne stanowiska w kwestiach istotnych dla strefy euro w ramach właściwych międzynarodowych instytucji i konferencji finansowych (art. 138 ust. 1 TFUE) ${ }^{54}$.

51 Ibidem, s. 142-143.

52 Ibidem, s. 140; Protokót w sprawie Eurogrupy, w: Traktat z Lizbony, op. cit., s. 365.

53 Traktat z Lizbony, op. cit., s. 143.

54 Ibidem, s. 140. 
Szósta zmiana sprowadza się do zniesienia wymogu jednomyślności i zastąpienia go głosowaniem większością kwalifikowaną przy uchwalaniu przez Radę, na wniosek Komisji Europejskiej, decyzji w sprawie rewizji niektórych ważnych postanowień Statutu ESBC i EBC. Rada i Parlament Europejski stanowią w tej sprawie na zalecenie EBC i po konsultacji z Komisją Europejską albo na wniosek Komisji Europejskiej i po konsultacji z EBC (art. 129 ust. 3 TFUE) ${ }^{55}$. Postanowienia te mają dotyczyć tak istotnych kompetencji EBC, jak ustalanie rezerwy obowiązkowej, system rozliczeń i płatności, dokonywanie operacji otwartego rynku, operacji kredytowych, a także operacji zewnętrznych. Zniesienie prawa weta Rady wobec wniosku Komisji Europejskiej lub zalecenia Europejskiego Banku Centralnego w sposób pośredni wzmacnia pozycję zarówno Komisji, jak i EBC we wspomnianej procedurze.

\section{Komitet Ekonomiczno-Społeczny}

Na mocy Traktatu lizbońskiego do TFUE wprowadzone zostają dwie istotne zmiany w działalności Komitetu Ekonomiczno-Społecznego. Po pierwsze, przedłużony zostaje z czterech do pięciu lat czas trwania kadencji członków Komitetu, z możliwością odnowienia mandatu. Lista członków Komitetu, sporządzona zgodnie z propozycjami każdego z państw członkowskich, ma być ustalana, podobnie jak dotąd, przez Radę, stanowiącą większością kwalifikowaną, po konsultacji z Komisją Europejską. Rada może zasięgać w tej sprawie opinii organizacji europejskich, których dotyczy działalność Unii, reprezentujących nie tylko - jak dotychczas - różne sektory gospodarcze i społeczne, ale także społeczeństwo obywatelskie (art. 302 ust. 1-2 TFUE) ${ }^{56}$. Po drugie, Komitet Ekonomiczno-Społeczny ma być odtąd konsultowany nie tylko przez Radę i Komisję Europejska, ale również przez Parlament Europejski, we wszystkich przypadkach przewidzianych $w$ traktatach, a także w innych przypadkach, które jedna z tych instytucji uzna za stosowane. Traktat włącza zatem po raz pierwszy Parlament Europejski do grona instytucji, które mają obligatoryjnie lub nieobligatoryjnie zasięgać opinii Komitetu Ekonomiczno-Społecznego (art. 304 TFUE) ${ }^{57}$.

\section{Komitet Regionów}

Wprowadzając zmiany do TFUE, Traktat lizboński ustanawia również dwie istotne zmiany w działalności Komitetu Regionów. Są one podobne do zmian ustanowionych w Komitecie Ekonomiczno-Społecznym. Przede wszystkim zwiększony zostaje z czterech do pięciu lat czas trwania kadencji członków Komitetu Regionów, z możliwością odnowienia mandatu (art. 305 TFUE) ${ }^{58}$. Druga zmiana polega natomiast na tym, że Traktat lizboński włącza po raz pierwszy Parlament Europejski do grona instytucji,

$\begin{array}{ll}55 & \text { Ibidem, s. } 136 . \\ 56 & \text { Ibidem, s. } 233 . \\ 57 & \text { Ibidem. } \\ 58 & \text { Ibidem, s. } 234 .\end{array}$ 
mających obligatoryjnie lub nieobligatoryjnie zasięgać opinii Komitetu Regionów we wszystkich przypadkach przewidzianych w traktatach oraz we wszelkich innych przypadkach, w szczególności gdy mają one związek ze współpracą transgraniczną (art. 307 TFUE) $)^{59}$.

\section{Uwagi końcowe}

Traktat lizboński z 13 grudnia 2007 r. umacnia zarówno instytucje współpracy międzyrządowej, jak i instytucje ponadnarodowe w systemie instytucjonalnym Unii Europejskiej, co oznacza utrzymanie przybliżonego parytetu pomiędzy nimi ukształtowanego $\mathrm{w}$ toku dotychczasowego procesu integracji począwszy od wejścia w życie Traktatów rzymskich z 25 marca 1957 r. Wzmocnieniu współpracy międzyrządowej służą przede wszystkim zmiany dotyczące statusu, składu i uprawnień Rady Europejskiej, a także struktury i zasad pełnienia przewodnictwa w Radzie. Natomiast dalszemu rozwojowi ponadnarodowej bazy instytucjonalnej i legislacyjnej sprzyja przede wszystkim wzmocnienie pozycji Parlamentu Europejskiego, Komisji Europejskiej i Trybunału Sprawiedliwości Unii Europejskiej w systemie instytucjonalnym. Rozszerzenie uprawnień legislacyjnych Parlamentu Europejskiego i Komisji Europejskiej oraz rozszerzenie kompetencji Trybunału Sprawiedliwości, pozwalające na objęcie jego jurysdykcją Rady Europejskiej, organów i jednostek organizacyjnych Unii, a także zwiększenia uprawnień jednostek (osób fizycznych i prawnych) w zakresie ochrony prawnej oznacza również istotne wzmocnienie metody wspólnotowej w przyszłej Unii Europejskiej. Zmiany w procedurze powoływania Komisji Europejskiej i Trybunału Sprawiedliwości ograniczają dotychczasowy wpływ, odpowiednio, Rady lub rządów państw członkowskich, a tym samym działają na korzyść zwolenników rozwiązań ponadnarodowych. Ponadnarodową infrastrukturę instytucjonalną i legislacyjną w Unii Europejskiej wzmacnia także nadanie wysokiemu przedstawicielowi Unii do spraw zagranicznych i polityki bezpieczeństwa rangi funkcjonariusza europejskiego (jako wiceprzewodniczącego Komisji Europejskiej) i wyposażenie go w prawo do inicjatywy prawodawczej.

59 Ibidem, s. 235. 
